\title{
KEPEMIMPINAN LEMBAGA PENDIDIKAN ISLAM
}

\author{
Oleh: Ushansyah \\ Dosen pada Sekolah Tinggi Agama Islam Kuala Kapuas
}

\begin{abstract}
Abstrak
Kepemimpinan merupakan kemampuan dan kesiapan yang dimiliki oleh seseorang untuk dapat mempengaruhi, mendorong, mengajak, menuntun, menggerakkan dan kalau perlu memaksa orang lain agar ia menerima pengaruh itu, dan selanjutnya berbuat sesuatu yang dapat membantu pencapaian tujuan-tujuan tertentu. Kepemimpinan pada hakekatnya berhubungan dengan tenaga manusia, hanya terdapat pada kelompok yang terorganisasi, dan sebagai satu kekuatan atau potensi. Di samping itu ciri-ciri dari seorang pemimpin dalam kepemimpinan pendidikan Islam antara lain adalah memiliki pengetahuan dan kemampuan yang cukup untuk mengendalikan lembaga atau organisasinya, memfungsikan keistimewaannya yang lebih dibanding orang lain, memahami kebiasaan dan bahasa orang yang menjadi tanggung jawabnya, mempunyai kharisma atau wibawa di hadapan manusia atau orang lain, bermuamalah dengan lembut dan kasih sayang terhadap bawahannya, agar orang lain simpatik kepadanya, bermusyawarah dengan para pengikut serta mintalah pendapat dan pengalaman mereka, mempunyai power dan pengaruh yang dapat memerintah serta mencegah karena seorang pemimpin harus melakukan control pengawasan atas pekerjaan anggota, meluruskan kekeliruan, serta mengajak mereka untuk berbuat kebaikan dan mencengah kemungkaran, dan bersedia mendengar nasehat dan tidak sombong, karena nasehat dari orang yang ikhlas jarang sekali kita peroleh
\end{abstract}

Kata Kunci: Kepemimpinan, Organisasi, Pendidikan Islam

\section{PENDAHULUAN}

$\begin{array}{lccr} & \text { Kepemimpinan dipahami sebagai } \\ \text { segala daya upaya } & \text { bersama untuk } \\ \text { menggerakkan semua sumber dan alat }\end{array}$ (resources) yang tersedia dalam suatu organisasi. Resources tersebut dapat digolongkan menjadi dua bagian besar, yaitu: human resource dan non human resources. Dalam lembaga pendidikan, khususnya lembaga pendidikan Islam yang termasuk salah satu unit organisasi juga terdiri dari berbagai unsur atau sumber, dan manusia merupakan unsur terpenting. Untuk itu dapat dikatakan bahwa sukses tidaknya suatu organisasi untuk mencapai tujuan yang telah ditetapkan sangat tergantung atas kemampuan pemimpinnya untuk menumbuhkan iklim kerja sama dengan mudah dan dapat menggerakkan sumber-sumber daya yang ada sehingga dapat mendayagunakannya dan dapat berjalan secara efektif dan efisien.

Dengan demikian, kehidupan suatu organisasi sangat ditentukan oleh peran seorang pemimpin. Kepemimpinan yang efektif Menurut Marno, Triyo Suppriyatno (2008; 30), adalah kepemimpinan yang mampu menumbuhkan dan mengembangkan usaha kerja sama serta memelihara iklim yang kondusif dalam kehidupan organisasi. Kepemimpinan yang baik adalah kepemimpinan yang dapat mengintegrasikan orientasi tugas dengan orientasi hubungan manusia

Dalam tulisan ini akan diuraikan seberapa penting peran kepemimpinan dalam lembaga pendidikan Islam. 


\section{PEMBAHASAN}

\section{A. Pengertian Kepemimpinan}

Mendefinisikan kepemimpinan merupakan suatu masalah yang komplek dan sulit, karena sifat dasar kepemimpinan itu sendiri memang sangat kompleks. Akan tetapi, perkembangan ilmu saat ini telah membawa banyak kemajuan sehingga pemahaman tentang kepemimpinan menjadi lebih sistematis dan objektif. Kepemimpinan melibatkan hubungan pengaruh yang mendalam yang terjadi di antara orang-orang yang menginginkan perubahan yang signifikan, dan perubahan tersebut mencerminkan tujuan yang dimiliki bersama oleh pemimpin dan pengikutnya (bawahan).

Kepemimpinan menurut Seokarto Indrafachrudi dkk., (1993; 23) adalah kemampuan dan kesiapan yang dimiliki oleh seseorang untuk dapat mempengaruhi, mendorong, mengajak, menuntun, menggerakkan dan kalau perlu memaksa orang lain agar ia menerima pengaruh itu dan selanjutnya berbuat sesuatu yang dapat membantu pencapaian tujuan-tujuan tertentu. Dari pengertian tersebut, dapat disimpulkan hal-hal yang penting mengenai kepemimpinan, antara lain:

1. Kepemimpinan itu pada hakekatnya berhubungan dengan tenaga manusia

2. Kepemimpinan itu pada hakekatnya hanya terdapat pada kelompok yang terorganisasi

3. Sebagai satu kekuatan atau potensi.

Pengaruh pemimpin itu pada pihak lain dapat memperkembangkan hubungan kemanusiaan yang lebih baik, dapat mempengaruhi pertumbuhan sikap-sikap yang positif dari pada individu-individu yang dipimpinnya. Tetapi yang paling penting ialah pengaruh kepemimpinannya sangat menentukan bagaimana kualitas kegiatan kerjasama dan kualitas hasil yang dapat dicapai oleh kegiatan kerjasama dalam lembaga tersebut.

\section{B. Ciri-ciri Seorang Pemimpin}

Mujamil Qomar (2007; 277), menyebutkan bahwa iri-ciri dari seorang pemimpin dalam kepemimpinan pendidikan Islam antara lain:

1. Memiliki pengetahuan dan kemampuan yang cukup untuk mengendalikan lembaga atau organisasinya.

2. Memfungsikan keistimewaannya yang lebih disbanding orang lain (QS. al-Baqarah: 247).

3. Memahami kebiasaan dan bahasa orang yang menjadi tanggung jawabnya (QS. Ibrahim: 4)

4. Mempunyai kharisma atau wibawa di hadapan manusia atau orang lain (QS. Huud: 91).

5. Bermuamalah dengan lembut dan kasih sayang terhadap bawahannya, agar orang lain simpatik kepadanya (QS. Ali Imran: 159).

6. Bermusyawarah dengan para pengikut serta mintalah pendapat dan pengalaman mereka (QS. Ali Imran: 159).

7. Mempunyai power dan pengaruh yang dapat memerintah serta mencegah karena seorang pemimpin harus melakukan control pengawasan atas pekerjaan anggota, meluruskan kekeliruan, serta mengajak mereka untuk berbuat kebaikan dan mencengah kemungkaran (QS al-Hajj: 41).

8. Bersedia mendengar nasehat dan tidak sombong, karena nasehat dari orang yang ikhlas jarang sekali kita peroleh (QS. alBaqarah: 206).

Selanjutnya, Mujamil Qomar (2007; 279), juga mengatakan bahwa jabatan pemimpin merupakan jabatan yang istimewa sebab, pemimpin organisasi apapun dipersyaratkan memiliki berbagai kelebihan menyangkut pengetahuan, perilaku, sikap, maupun keterampilan dibanding orang lain. Pada umumnya, seseorang memiliki kelebihan- 
kelebihan tertentu, tetapi sebaliknya juga memiliki kelemahan-kelemahan tertentu.

Figur pemimpin yang ideal sangatlah diharapkan oleh masyarakat, lantaran seorang pemimpin menjadi contoh terbaik dalam segala ucapan, perbuatan, dan kebiasaan, termasuk dalam hal berpakaian. Dalam konteks pendidikan Islam, pemimpin harus memiliki keunggulan yang lebih lengkap. Dasar filosofinya adalah pendidikan Islam selama ini mengklaim sebagai lembaga yang berusaha keras membangun kecerdasan intelektual, keshalehan social, dan kemantapan spiritual.

\section{Peran Kepemimpinan dalam Lembaga Pendidikan Islam}

Salah satu bentuk kepemimpinan dalam lembaga pendidikan Islam adalah kepala sekolah. Menurut Mulyasa (2004; 24), kepala sekolah merupakan salah satu komponen pendidikan yang paling berperan dalam menentukan keberhasilan suatu lembaga pendidikan, karena ia merupakan pemimpin di lembaganya. Lebih lanjut ia mengatakan bahwa kegagalan dan keberhasilan sekolah banyak ditentukan oleh kepala sekolah, karena mereka merupakan pengendali dan penentu arah yang hendak ditempuh sekolah menuju tujuannya, yaitu sekolah yang efektif, bermutu, dan favorit tidak lepas dari peran kepala sekolahnya. maka ia harus mampu membawa lembaganya ke arah tercapainya tujuan yang telah ditetapkan, ia harus mampu melihat adanya perubahan serta mampu melihat masa depan dalam kehidupan global yang lebih baik. Kepala sekolah harus bertanggung jawab atas kelancaran dan keberhasilan semua urusan pengaturan dan pengelolaan sekolah secara formal kepada atasannya atau secara informal kepada masyarakat yang telah menitipkan anak didiknya.
Di negara maju kepala sekolah mendapat sebutan bermacam-macam. Ada yang menyebut guru kepala (head teacher atau head master), kepala sekolah (principal), kepala sekolah yang mengajar (teaching principal), direktur (director), administrator, pemimpin pendidikan (educational leadership) Mantja (1996; 26). Sedangkan menurut Marno, Triyo Suppriyatno, (2008; 34), adanya kriteria yang mempersyaratkan kompetensi professional kepala sekolah sebagai administrator. Kepala sekolah harus mampu mendayagunakan sumber yang tersedia secara optimal. Sebagai manajer, kepala sekolah harus mampu bekerjasama dengan orang lain dalam organisasi sekolah. Sebagai pemimpin pendidikan, kepala sekolah harus mampu mengkoordinasi dan menggerakkan potensi manusia untuk mewujudkan tujuan pendidikan. Sebagai supervisor, kepala sekolah harus mampu membantu guru meningkatkan kapasitasnya untuk membelajarkan murid secara optimal.

Sebagai pemimpin pendidikan yang professional, kepala sekolah dituntut untuk selalu mengadakan perubahan. Mereka harus memiliki semangat yang berkesinambungan untuk mencari terobosan-terobosan baru demi menghasilkan suatu perubahan yang bersifat pengembangan dan penyempurnaan, dari kondisi yang memprihatinkan menjadi kondisi yang lebih dinamis, baik segi fisik maupun akademik seperti perubahan semangat keilmuan, atmosfer belajar dan peningkatan strategi pembelajaran. Di samping itu, kepala sekolah juga harus berusaha keras menggerakkan para bawahannya untuk berubah, setidaknya mendukung perubahan yang dirintis kepala sekolah secara proaktif, dinamis, bahkan progresif. Sistem kerja para bawahan harus lebih kondusif. Kinerja mereka harus dirangsang supaya meningkat. Disiplin mereka harus dibangkitkan. Sikap kerjasama mereka lebih 
dibudayakan, dan suasana harmonis di antara mereka lebih diciptakan.

Pada dasarnya tugas kepala sekolah itu sangat luas dan kompleks rutinitas kepala sekolah menyangkut serangkai pertemuan interpersonal secara berkelanjutan dengan murid, guru dan orang tua, atasan dan pihak-pihak terkait lainnya. Blimberg (1987) membagi tugas kepala sekolah sebagai berikut: (1) menjaga agar segala program sekolah berjalan se-damai mungkin; (2) menangani konflik atau menghindarinya; (3) memulihkan kerjasama; (4) membina para staf dan murid (5) mengembangkan organisasi, dan (6) mengimplementasi ide-ide pendidikan. Untuk memenuhi tugas-tugas di atas, dalam segala hal hendaknya kepala sekolah berpegangan kepada teori sebagai pembimbing tindakannya. Teori in didasarkan pada pengalamannya, karakteristik normatif masyarakat dan sekolah, serta iklim instruksional dan organisasi sekolah, misalnya kepala suatu madrasah harus mampu menunjukkan bahwa segala tindakan profesionalnya sesuai dan tidak bertentangan dengan nilai-nilai al-Qur'an dan sunnah Nabi. Hal itu dapat ditempuh dengan merefleksi dan mengkonstruksi uswah rasul dan para shahabat di samping mengembangkan kompetensi dan kualitas dirinya.

Kualitas dan kompetensi kepala sekolah secara umum setidaknya mengacu kepada empat hal pokok, yaitu: (a) sifat dan keterampilan kepemimpinan, (b) kemampuan pemecahan masalah, (c) keterampilan sosial, dan (d) pengetahuan dan kompetensi professional. Secara garis besar kualitas dan kompetensi kepala sekolah menurut Marno, Triyo Suppriyatno, (2008; 39) dapat dinilai dari kinerjanya dalam mengaktualisasikan fungsi dan perannya sebagai kepala sekolah yaitu meliputi:

1. Sebagai Pendidik (educator)

a. Kemampuan membimbing guru dalam melaksanakan tugas. b. Mampu memberikan alternative pembelajaran yang efektif.

c. Kemampuan membimbing bermacammacam kegiatan kesiswaan.

2. Sebagai Manajer

a. Kemampuan menyusun organisasi personal dengan uraian tugas sesuai dengan standar yang ada.

b. Kemampuan menggerakkan stafnya dan segala sumber daya yang ada serta lebih lanjut memberikan acuan yang dinamis dalam kegiatan rutin dan temporer.

c. Kemampuan menyusun program secara sistematis.

\section{Administrator}

a. Kemampuan mengelola semua perangkat KBM secara sempurna dengan bukti berupa data administrasi yang akurat

b. Kemampuan mengelola administrasi kesiswaan, ketenagaan, keuangan, sarana dan prasarana, dan administrasi persuratan dengan ketentuan yang berlaku.

4. Sebagai Supervisor

Kegiatan utama pendidikan di sekolah dalam rangka mewujudkan tujuannya adalah kegiatan pembelajaran sehingga seluruh aktivitas organisasi sekolah bermuara pada pencapaian efisiensi dan efektivitas pembelajaran. Oleh Karena itu salah satu tugas kepala sekolah adalah sebagai supervisor, yaitu melakukan supervisi terhadap pekerjaan yang dilakukan oleh tenaga kependidikan.

a. Kemampuan menyusun program supervise pendidikan di lembaganya yang dapat melaksanakan dengan baik.

b. Kemampuan memanfaatkan hasil supervisi untuk peningkatan kinerja guru dan karyawan.

c. Kemampuan memanfaatkan kinerja guru atau karyawan untuk pengembangan dan peningkatan mutu pendidikan. 


\section{Pemimpin}

Kepala sekolah sebagai leader harus mampu memberikan petunjuk dan pengawasan, meningkatkan kemampuan tenaga kependidikan, membuka komunikasi dua arah, dan mendelegasikan tugas. Kemampuan yang harus diwujudkan kepala sekolah sebagai leader dapat dianalisis dari kepribadian, pengetahuan terhadap tenaga kependidikan, visi dan misi sekolah, kemampuan mengambil keputusan dan kemampuan berkomunikasi. kepribadian kepala sekolah sebagai leader tercermin dalam sifat-sifat jujur, percaya diri, tanggungjawab, berani mengambil resiko, dan keputusan, berjiwa besar, emosi yang stabil, teladan.

\section{Sebagai Inovator}

Kepala sekolah sebagai inovator akan tercermin dari cara-cara ia melakukan pekerjaannya secara konstruktif, kreatif, delegatif, integratif, rasional dan obyektif, pragmatis, keteladanan, disiplin, serta fleksibel.

\section{Teori Kepemimpinan}

Ada dua teori kepemimpinan menurut Isjoni (2007; 33) yang cukup menarik perhatian para pengamat dan praktisi pengembangan sosial antara lain sebagai berikut:

\section{Teori kepemimpinan kharismatik (charis- matic leadership)}

Pemimpin-pemimpin kharismatik menampilkan ciri-ciri sebagai berikut:

a. Memiliki visi yang amat kuat atau kesadaran tujuan yang jelas

b. Mengkomunikasikan visi itu dengan efektif

c. Mendemonstrasikan konsistensi dan fokus d. Mengetahui kekuatan- kekuatan sendiri dan memanfaatkannya.

2. Teori kepemimpinan transformasional (transformational leadership)

Pemimpin-pemimpin transaksional membimbing atau memotivasi pengikutnya atau bawahannya ke arah tujuan yang telah ditentukan dengan cara menjelaskan ketentuan-ketentuan peran dan tugas. Pemimpin transformasional memberikan pertimbangan yang bersifat individual, stimulasi intelektual dan memiliki kharismatik. Kepemimpinan transformational dibangun dari kepemimpinan transaksional.

\section{E. Tipe kepemimpinan}

\section{Partisipatif}

Kepemimpinan yang partisipatif menurut Isjoni (2007; 58) adalah suatu cara memimpin yang memungkinkan para bawahan turut serta dalam proses pengambilan keputusan. Bila ternyata proses tadi mempengaruhi kelompok, atau bila memang kelompok (bawahan) ini mampu turut berperan dalam pengambilan keputusan dalam hal ini atasan tidak hanya memberikan kesempatan kepada mereka yang berinisiatif akan tetapi akan membantu mereka menyelesaikan tugas mereka sendiri, umpamanya dengan memberikan fasilitas. Pemimpin di sini bermaksud untuk mengembangkan rasa tanggung jawab bawahan dalam mencapai tujuan kelompok, organisasi atau lembaga, dengan menggunakan cara memberi pujian, atau juga memberikan kritik yang membangun walau pada akhirnya tanggung jawab untuk membuat keputusan itu ada tangan pemimpin namun dalam prosesnya, pengambilan keputusan itu dikerjakan bersama-sama dalam anggota kelompok. 


\section{Laissez faire (bebas)}

Dengan cara ini seorang pemimpin akan meletakkan tanggung jawab pengambilan keputusan sepenuhnya kepada para bawahan. Di sini pemimpin hanya sedikit saja atau hampir sama sekali tidak memberikan pengarahan. Sudah barang tentu dengan cara ini maksud pemimpin adalah menganggap bawahannya sudah dewasa, dan tahu apa kewajibannya. Dalam cara ini komunikasi antar bawahan, maupun antara bawahan dan pemimpinnya kurang sekali.

\section{F. Beberapa Permasalahan yang Dihadapi oleh Seorang Pemimpin}

Jenis dan bentuk konflik itu memiliki implikasi dan konsekuensi bagi manajer lembaga pendidikan Islam. Karena, manajer memiliki peran yang fungsional dalam mengelola konflik dan diharapkan mampu mengelolanya sebaik mungkin sehingga menghasilkan kepuasan bagi semua pihak, terutama pihak yang berkonflik. Setidaknya, mereka tidak lagi membuat ulah yang berpotensi menyulut konflik baru pasca penyelesaian konflik. Di samping itu, hal ini juga menuntut pemimpin untuk bisa memberi teladan bagi dirinya sendiri maupun orang lain. Contoh bagi diri sendiri sering kali kurang bisa direalisasi oleh para pemimpin. Maka, pemimpin pendidikan Islam harus belajar dan menghayati kasus yang di alami, harus disadari bahwa memerintah diri sendiri terkadang lebih sulit dibanding memerintah orang lain.

Tugas seorang pemimpin lembaga pendidikan Islam harus mampu menyelesaikan permasalahan atau konflik yang sedang dihadapinya, seperti menurut Mujamil Qomar (2007; 24) sebagai berikut:

1. Konflik diri sendiri, seperti kepala madrasah pada waktu yang sama dihadapkan pada pilihan delimatik antara pergi ke madrasah tepat waktu sebagaimana ketentuan yang sudah disepakati atau kepentingan mengantar isteri ke pasar, karena memiliki hajat yang sangat penting. Memilih dua kepentingan ini benar-benar menimbulkan konflik dalam dirinya yang sama-sama beresiko. Dan ternyata tidak banyak kepala madrasah yang memilih pergi ke madrasah tepat waktu sebagai teladan bagi bawahannya dengan menunda kepentingan keluarga (isteri).

2. Konflik antar pemimpin madrasah dengan ketua yayasan. Konflik antar pemimpin ini sangat menggangu proses pembelajaran dan tentu berdampak negatif pada mutu hasil pembelajaran atau pendidikan. Konflik semacam ini merupakan konflik tingkat tinggi, karena terjadi pertentangan antar pimpinan, yaitu konflik antar pimpinan penyelenggara pendidikan (ketua yayasan) dengan pimpinan pelaksana pendidikan (kepala madrasah). Di Indonesia disinyalir banyak yayasan yang mengharapkan pendapatan finansial dari pelaksana pendidikan, padahal pihak pelaksana pendidikan sendiri juga kesulitan untuk memenuhi kebutuhan dasar madrasah

3. Konflik antar pemimpin madrasah dengan guru, dalam hal ini hubungan antar pemimpin madrasah dengan guru kadang tidak harmonis, dikarenakan adanya perbedaan pendapat dalam musyawarah ataupun dalam penyelesaian masalah. Hal semacam ini sering terjadi di madrasahmadrasah.

4. Konflik antar pemimpin madrasah dengan ketua komite (masalah dana pembiayaan operasional madrasah). Seperti, dalam rapat untuk penentuan dana pembangunan madrasah, adanya perselisihan pendapat antar keduanya dalam pengambilan keputusan dana tersebut. 
Berkaitan dengan permasalahan atau konflik di atas penulis mencoba untuk memberikan solusi, sebagai berikut:

1. Untuk mengatasi konflik pribadi di atas hendaknya seorang pemimpin mempunyai keprofesionalan untuk membedakan antara kepentingan pribadi dan kepentingan lembaga. Seorang pemimpin harus mengutamakan kepentingan lembaga di atas kepentingan pribadi.

2. Dalam hal mengatasi konflik antar pemimpin madrasah dengan ketua yayasan seperti di atas, diperlukan suatu upaya untuk menyinkronkan permasalahan. Kedua belah pihak perlu bertemu untuk membahas dan merumuskan jalan keluar dari permasalahan yang ada sehingga tercapai suatu kemufakatan untuk kepentingan bersama.

\section{KESIMPULAN}

Salah satu bentuk kepemimpinan dalam lembaga pendidikan Islam adalah kepala sekolah. Kepala sekolah merupakan salah satu komponen pendidikan yang paling berperan dalam menentukan keberhasilan suatu lembaga pendidikan. Karena ia merupakan pemimpin di lembaganya, Kualitas dan kompetensi kepala sekolah secara umum setidaknya mengacu kepada empat hal pokok, yaitu: (a) sifat dan keterampilan kepemimpinan, (b) kemampuan pemecahan masalah, (c) keterampilan sosial, dan (d) pengetahuan dan kompetensi professional.

Fungsi dan perannya sebagai kepala sekolah adalah sebagai pendidik, sebagai manajer, sebagai administrator, supervisor, pemimpin dan innovator, sehingga tujuan yang telah ditetapkan menjadi efektif dan efisien.

\section{DAFTAR PUSTAKA}

Indrafachrudi, Seokarto dkk, Pengantar Kepemimpinan Pendidikan, Surabaya: Usaha Offset Printing, 1993.

Isjoni, Manajemen Kepemimpinan dalam Pendidikan, Bandung: Sinar Baru Algensindu, 2007.

Marno, Triyo Suppriyatno, Manajemen dan Kepemimpinan Pendidikan Islam, Bandung: Refika Aditma, 2008.

Mulyasa, E, Menjadi Kepala Sekolah Professional, Bandung: PT Remaja Rosdakarya, 2004.

Qomar, Mujamil, Manajemen Pendidikan Islam, Jakarta: Erlangga, 2009. 